\title{
NELAYAN INDONESIA DALAM PUSARAN KEMISKINAN STRUKTURAL (PERSPEKTIF SOSIAL, EKONOMI DAN HUKUM)
}

\author{
Endang Retnowati \\ Fakultas Hukum Universitas Wijaya Kusuma Surabaya \\ e-mail: endangretnowati49@yahoo.co.id
}

\begin{abstract}
ABSTRAK
Indonesia sebagai Negara Kepulauan, yang luas wilayahnya 70\% merupakan wilayah lautan. Di wilayah lautan ini terkandung potensi ekonomi kelautan yang sangat besar dan beragam, antara lain sumber daya ikan. Dengan melimpahnya sumber daya ikan maka seharusnya pendapatan nelayan sangatlah memadai untuk memenuhi kebutuhan hidupnya. Namun dalam realita tidaklah demikian, kemiskinan masih banyak melanda kehidupan nelayan. Dari sisi ekonomi hasil tangkapan nelayan masih jauh dari memadahi untuk memenuhi kebutuhan hidupnya. Hal ini disebabkan karena minimnya modal yang dimiliki nelayan, tekanan dari pemilik modal, sistem bagi hasil yang tidak adil, perdagangan atau pelelangan ikan yang tidak transparan (dikuasai tengkulak) dan otoritas tidak punya wibawa untuk mengatur dan menegakkan aturan. Serta pola atau budaya kerja yang masih apa adanya. Kondisi kemiskinan yang dialami nelayan menyebabkan mereka rentan konflik dan hanya menjadi objek. Hukum yang seharusnya memberikan perlindungan ternyata juga tidak optimal. Dalam Undang-Undang Perikanan hanya ada 2 ayat dalam pasal 1 yang mengatur nelayan, itu pun hanya ayat yang memberikan pengertian nelayan dan nelayan kecil. Bahkan pengertian itu pun berbeda dengan pengertian nelayan tradisional dalam penjelasan pasal 18 (6) Undang-Undang Pemerintahan Daerah serta dalam realitasnya. Perbedaan pengertian ini berdampak pada nelayan.
\end{abstract}

Kata kunci: kemiskinan, nelayan.

\begin{abstract}
Indonesia as an archipelago, which has till $70 \%$ is ocean area. In this sea area marine contains a very large and varied economic potential including fish resources. With the abundance of fish resources, it should make the fishermen earning to complete their necessities. In fact, it is not so, the poverty still have been collided with the lives of many fishermen. From the economic side, what the fishermen catch, is so far from enough to complete their necessities. This is caused by lack of capital owned by fishermen, the pressure from the owners of capital, profit-sharing system that is not fair, trade or auctioning process of fish that are not transparent (controlled by middlemen). Furthermore the authorities have no authority to regulate and enforce the rules. In addition, the pattern or work culture that is still what it is. The conditions of poverty which is experienced by fishermen led to their conflict and only to be the object. The law should provide protection has not been optimal yet. In the fishery law, there are only 2 verse in paragraph 1 regulating fishermen, also it is only the verse giving understanding of fishermen and small fishermen. Even it gives different understanding that traditional fishermen in the explanation of paragraph 18 (6) Local Government Act as well as in reality. The different understanding gives impact to the fishermen.
\end{abstract}

Keywords: poverty, fishermen

\section{PENDAHULUAN}

Indonesia merupakan Negara Kepulauan (archipelagic state) terbesar di dunia, yang terdiri dari 5 pulau besar dan 30 kepulauan kecil, jumlah keseluruhan tercatat ada sekitar 17.504 pulau, 8.651 pulau sudah ber- nama, 8.853 pulau belum bernama, dan 9.842 pulau yang telah diverifikasi (Depdagri, 2006). Kondisi geografis yang strategis terbentang sepanjang 5.150 km di antara benua Australia dan Asia serta membelah Samudra Hindia dan Samudra Pasifik di bawah 
garis khatulistiwa (www.wikipedia.com). Wilayah Negara Republik Indonesia meliputi wilayah daratan dan wilayah air yang meliputi: perairan pedalaman, perairan kepulauan, laut teritorial, dasar laut, beserta tanah dibawahnya, serta ruang udara diatasnya, termasuk seluruh sumber kekayaan yang terkandung didalamnya (Konsideran UU RI No. 43 Tahun 2008 tentang wilayah Negara, LNRI No. 177 Tahun 2008). Wilayah air yang untuk sebagian besar dari wilayah Indonesia merupakan wilayah lautan yang meliputi 5,8 juta $\mathrm{km}^{2}$ atau $70 \%$ dari luas total teritorial Indonesia (www.wikipedia.com).

Sehingga dengan kondisi wilayah yang demikian ini, disamping sebagai Negara kepulauan, Negara Indonesia juga dikatakan sebagai Negara Bahari (Maritim). Berdasarkan Pasal 46 Konvensi Perserikatan Bangsa-Bangsa tentang Hukum Laut (UNCLOS 1982), Negara Kepulauan berarti suatu negara yang seluruhnya terdiri dari satu atau lebih kepulauan dan dapat mencakup pulau-pulau lain. Selanjutnya ditegaskan dalam Pasal 2 ayat (1) Undang-Undang Republik Indonesia No. 6 Tahun 1996 tentang Perairan Indonesia; Negara Republik Indonesia adalah Negara Kepulauan. Keseluruhan luas laut Indonesia (Total Indonesian Waters) 5,8 juta $\mathrm{km}^{2}$ yang terdiri: luas perairan kepulauan atau laut Nusantara (Total Archipelagic Waters) 2,3 juta $\mathrm{km}^{2}$; luas Perairan Teritorial (Total Territorial Waters) 0,8 juta $\mathrm{km}^{2}$; Luas Perairan ZEE Indonesia (Total EEZ of Indonesian Waters) 2,7 juta km²; dan Panjang garis Pantai (Coast Line of Indonesian) $95.181 \mathrm{~km}$. (Kementerian Kelautan dan Perikanan, 2009:1)

Negara Kesatuan Republik Indonesia sebagai Negara kepulauan yang bercirikan nusantara, mempunyai kedaulatan penuh atas wilayahnya maupun hak-hak berdaulat atau hak-hak eksklusif di luar wilayah kedaulatannya (Zona Ekonomi Eksklusif) dan kewenangan atau yurisdiksi tertentu untuk mengelola dan memanfaatkan sebesar-besarnya bagi kesejahteraan dan kemakmuran rakyat Indonesia. Sebagaimana diamanatkan dalam Pembukaan Undang-Undang Dasar Negara Republik Indonesia Tahun 1945 bahwa tujuan dibentuknya Negara Republik Indonesia diantaranya adalah Kesejahteraan Umum, dan Pasal 33 ayat (3) Undang Undang Dasar Negara Republik Indonesia Tahun 1945: "Bumi dan air dan kekayaan alam yang terkandung di dalamnya dikuasai oleh negara dan dipergunakan untuk sebesar-besarnya kemakmuran rakyat".

Kondisi geografis dan wilayah Negara Republik Indonesia yang merupakan Negara Kepulauaan dan Negara Bahari (Maritim) yang demikian ini sangat menguntungkan bagi bangsa dan negara Indonesia karena didukung adanya potensi atau kekayaan yang berupa Sumber Daya Alam (SDA) yang ada di wilayah tersebut. Sumber Daya Alam (SDA) yang merupakan kekayaan alam Indonesia meliputi bentuk Modal Alam (natural resources stock), seperti daerah aliran sungai (watershed), danau, kawasan lindung, pesisir dan lain-lain, dan dalam bentuk faktor produksi (komoditas) seperti kayu, rotan, air, mineral, ikan, tambang dan sebagainya. Sumber Daya Alam ini dapat dikategorikan pula menjadi Sumber Daya Alam yang dapat diperbarui atau dipulihkan (renewable) dan Sumber Daya Alam yang tidak dapat diperbarui atau dipulihkan (non renewable). (I Nyoman Nurjaya, 2009:94)

Selain Sumber Daya Alam yang dimiliki, Indonesia juga kaya akan Sumber Daya Manusia (SDM) yang sangat beragam suku dan budaya yang sangat bernilai, yang tidak dimiliki oleh negara lain. Jumlah penduduk Indonesia tercatat sampai dengan Tahun 2010 berdasarkan sensus penduduk yang diselenggarakan oleh Badan Pusat Statistik (BPS) ada 237.556.363 orang, yang terdiri dari 119.509.580 lakilaki dan 118.048 .783 perempuan. (BPS, 2010)

Di wilayah lautan Indonesia terkandung potensi ekonomi kelautan yang sangat besar dan beragam. Sedikitnya terdapat 13 (tiga belas) sektor yang ada di lautan, yang dapat dikembangkan serta dapat memberikan kontribusi bagi perekonomian dan kemakmuran masyarakat Indonesia, yaitu meliputi: a. Perikanan tangkap, b. Perikanan budidaya, c. Industri pengolahan hasil budidaya, d. Industri bioteknologi kelautan, e. Pertambangan dan energi, f. Pariwisata bahari, g. Transportasi laut, h. Industri dan jasa maritim, i. Pulau-pulau kecil, j. Sumber daya non-Konvensional, $\mathrm{k}$. Bangunan kelautan, l. Benda-benda berharga dan warisan budaya, m. Jasa lingkungan Konversi dan Biodiversitas.

Sebagai sebuah sistem dari keseluruhan pengelolaan potensi laut yang ada tersebut, bidang perikanan dapat dijadikan sebagai indikator yang baik bagi pengelolaan laut. Dikarenakan di sektor tersebut terdapat sumber daya ikan yang sangat besar. Sehingga perikanan sebagai salah satu SDA yang mempunyai peranan penting dan strategis dalam pembangunan perekonomian nasional terutama dalam meningkatkan perluasan kesempatan kerja, pemerataan pendapatan dan peningkatan taraf hidup bangsa pada umumnya, nelayan kecil, pembudidaya ikan kecil dan pihakpihak pelaku usaha di bidang perikanan dengan tetap memelihara lingkungan, kelestarian dan ketersediaan sumber daya. (Rohmin Danuri) 
Ikan pada dasarnya merupakan Sumber Daya Alam (SDA) yang dikategorikan sebagai SDA yang dapat diperbarui atau dipulihkan. Namun, hal ini tidak berarti bahwa sumber daya ikan tersebut dapat ditangkap secara sembarangan, misalnya dengan menggunakan bahan-bahan peledak atau menggunakan alat tangkap yang dapat mengakibatkan kerusakan lingkungan atau ekologi laut maupun melakukan tangkap lebih (over eksploitasi). Untuk mendukung pemulihan sumber daya ikan sangat diperlukan faktor pendukung yang lain, yakni faktor lingkungan laut atau ekologi laut, misalnya terumbu karang, yang meskipun terumbu karang ini dapat diperbarui atau dipulihkan namun pemulihannya memerlukan waktu yang sangat lama dan biaya yang besar.

Untuk diketahui bahwa potensi sumber daya ikan Indonesia diperkirakan adalah 6,4 juta ton per tahun, dari jumlah tersebut 1,26 juta ton berasal dari Zona Ekonomi Eksklusif Indonesia (ZEEI) (Rohmin Danuri). Berdasarkan Pasal 1 angka 8 UndangUndang Republik Indonesia No. 43 tahun 2008 tentang Wilayah Negara, yang dimaksud ZEEI adalah suatu area di luar dan berdampingan dengan laut teritorial Indonesia sebagaimana dimaksud dalam Undang-Undang yang mengatur mengenai Perairan Indonesia, dengan batas terluar 200 (dua ratus) mil laut dari garis pangkal dari mana lebar laut teritorial diukur. Adapun yang dimaksudkan dengan UndangUndang yang mengatur tentang Perairan Indonesia disini adalah Undang-Undang Republik Indonesia No. 6 Tahun 1996 tentang Perairan Indonesia.

Jika berpedoman kepada prinsip kelestarian, sumber daya yang seharusnya boleh ditangkap ( $m a x-$ imun sustainable yield) hanya $80 \%$ dari potensi yang ada tersebut, atau berarti 5,12 juta ton per tahun. Sementara produksi perikanan tangkap tahun 2006 adalah 4.806.112 ton, tahun 2007 adalah 5.044.737 ton sedangkan tahun 2008 adalah 5.176.090 ton. Apabila memperhatikan perolehan atau produksi tangkapan ini maka dalam setiap tahun telah terjadi peningkatan produksi tangkap (Departemen Kelautan dan Perikanan, 2008). Dampak yang dapat timbul apabila maximum sustainable yield (MSY) ini dilanggar maka akan terjadi tangkap lebih (over fishing). Untuk menjaga keberlanjutan sumber daya ikan, Indonesia menetapkan jumlah tangkapan yang diperoleh atau yang boleh ditangkap atau maximum sustainable yield, mengatur tentang jenis alat tangkap yang diperbolehkan dan dilarang, serta lokasi penangkapan yang pada dasarnya disesuaikan dengan jenis alat tangkap dan berat kapal penangkapan, melalui pengaturan dalam ketentuan Undang-Undang Perikanan.
Luas wilayah perairan Indonesia kurang lebih 5,8 juta kilometer persegi, dan jumlah nelayan di Indonesia hingga tahun 2009 tercatat 2.752 .490 orang dengan total armada 596.230 unit. Dari jumlah nelayan tersebut $90 \%$ nya merupakan nelayan kecil dengan bobot mati kapal di bawah 30 Gross Tonnage (GT) (Departemen Kelautan dan Perikanan, 2008). Hal ini menunjukkan secara umum masih dianggap seimbang, antara luas perairan dengan jumlah nelayan, meskipun untuk beberapa daerah tertentu (misalnya selat Madura) terjadi jumlah nelayan terlalu banyak, tidak sebanding dengan wilayah penangkapan yang ada, sehingga jika terjadi hal sedemikian maka akan berpotensi menimbulkan tangkap lebih (over fishing), yang pada akhirnya dapat memicu konflik antar nelayan karena perebutan wilayah dan ikan tangkapan (Departemen Kelautan dan Perikanan, 2008). Bahwasanya sampai saat ini di Indonesia belum ada ketentuan pembatasan jumlah nelayan dan persyaratan menjadi nelayan. Salah satu faktor sulitnya membatasi jumlah nelayan dan persyaratannya, karena padatnya jumlah penduduk, jumlah pengangguran yang banyak sementara peluang kerja terbatas. Peluang yang ada dan sangat mudah tanpa adanya persyaratan formalitas adalah nelayan. Kemiskinan yang dialami oleh sebagian masyarakat pesisir karena faktor ekonomi dan sosial, sehingga mereka tidak mampu untuk mendapatkan pendidikan yang memadai menjadi satu alasan untuk memilih menjadi nelayan.

Sumber daya ikan adalah salah satu sumber daya ekonomi, oleh karena itu sumber daya ikan merupakan modal bagi pembangunan bangsa Indonesia. Sebagai sumber daya yang bersifat dapat pulih kembali (renewable) dan yang merupakan modal pembangunan ekonomi, maka sumber daya ikan tersebut harus dapat dimanfaatkan secara berkelanjutan dengan batas-batas pemanfaatannya disesuaikan dengan daya dukung sumber daya ikan dan daya tampung suatu perairan.

Berdasarkan sifat-sifat sumber daya ikan tersebut di atas, maka sumber daya ikan harus dikelola dan dimanfaatkan secara bertanggung jawab, yaitu dengan memperhatikan kelestarian sumber daya ikan dan lingkungannya, sehingga sumber daya ikan dapat merupakan sumber daya pembangunan yang berkelanjutan. Prinsip bertanggung jawab dimaksudkan adalah mengacu pada Kode Etik Perikanan yang Bertanggung Jawab atau "Code of Conduct for Responsible Fisheries (CCRF)". CCRF ini telah disepakati bersama oleh anggota FAO, dimana CCRF ini telah menjadi semacam pedoman umum bagi setiap negara dalam pembangunan perikanan. Indonesia sebagai 
salah satu negara anggota FAO dengan sendirinya dalam pengelolaan perikanan juga harus berpedoman pada CCRF tersebut dan dalam CCRF antara lain menekankan perlunya disusun Rencana Pengelolaan Perikanan Wilayah. Pentingnya menyusun Pencana Pengelolaan Perikanan Wilayah agar tidak terjadi eksploitasi sumber daya ikan yang tidak terkendali dan Rencana Pengelolaan Perikanan harus disusun bersama oleh Pemerintah dengan stakeholders.

Selain ketentuan yang diatur dalam CCRF tersebut, untuk mendukung pengelolaan perikanan yang bertanggung jawab serta berkelanjutan di Indonesia diatur ketentuan tentang perikanan, yaitu: dalam Undang Undang Republik Indonesia No. 31 tahun 2004 tentang Perikanan (LNRI No. 118, TLNRI No. 4433); jo Undang-Undang Republik Indonesia No. 45 Tahun 2009 tentang Perubahan atas Undang-Undang No. 31 Tahun 2004 tentang Perikanan (LNRI Tahun 2009 No. 154) selanjutnya dalam penulisan ini cukup disebut Undang-Undang Perikanan.

Dengan memperhatikan luasnya wilayah laut yang dimiliki Indonesia serta melimpahnya sumber daya ikan yang dikandungnya maka secara logika menunjukkan terbukanya peluang kerja di sektor ini dan adanya kehidupan nelayan yang mapan. Namun dalam realitanya kehidupan nelayan Indonesia masih sangat memprihatinkan. Kemiskinan masih dijumpai di daerah-daerah pesisir, nelayan rentan terhadap konflik antar mereka. Tulisan ini membahas tentang keberadaan nelayan baik dari sisi sosial, ekonomi dan hukum. Diharapkan adanya tulisan ini memberikan kontribusi dan pemahaman tentang keberadaan nelayan Indonesia.

\section{PEMBAHASAN}

Secara umum nelayan diartikan sebagai orang yang mata pencahariannya menangkap ikan, penangkap ikan di laut (W.J.S. Purwodarminto, h.674). Berdasarkan kepentingan dan latar belakangnya nelayan dibedakan:

"Fisher around the world seems to fit within four principal categories, based on the nature of, and back ground to, their particular fishing activities: Subsistence fishers: those catching fish as their own source of food; Native aboriginal fisher: those belonging to aboriginal groups, often fishing for subsistence; Recreational fisher: those catching fish principally for their own enjoyment; Commercial fisher: those catching fish for sale in domestic or export markets, these fishers are traditionally viewed as falling into artisanal and industrial categori. (Anthony T. Charles, 2001:45)

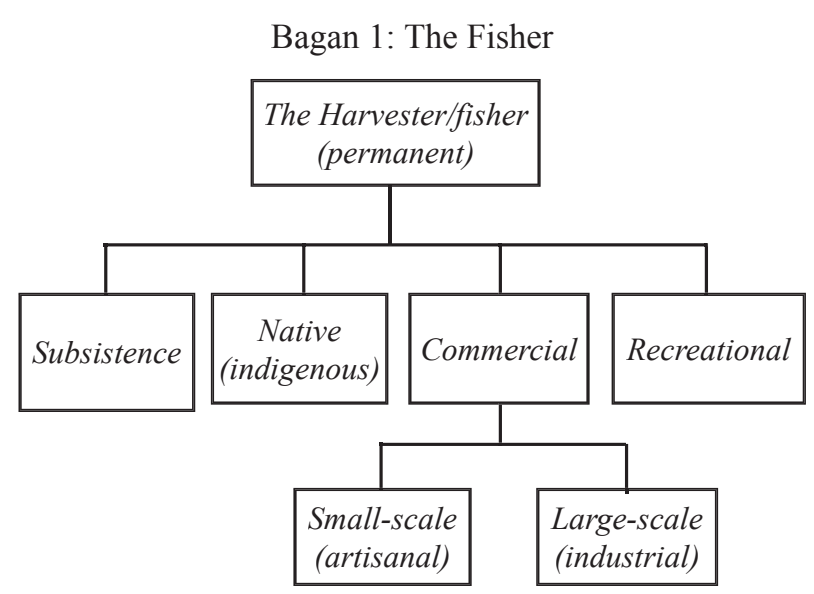

Sumber: Anthony T. Charles, Suistainable Fishery System, Fish and Aquatic Resources Series, Oxford: Blackwell Science, 2001.

Menurut Pasal 1 Undang-Undang Republik Indonesia No. 6 tahun 1964 tentang Bagi Hasil Perikanan (LNRI No. 97 tahun 1964, TLN No. 2690), pengertian nelayan dibedakan menjadi dua yaitu: nelayan pemilik dan nelayan penggarap. Nelayan pemilik ialah orang atau badan hukum yang dengan hak apapun berkuasa atas sesuatu kapal atau perahu yang dipergunakan dalam usaha penangkapan ikan dan alatalat penangkapan ikan. Nelayan penggarap ialah semua orang yang sebagai kesatuan dengan menyediakan tenaganya turut serta dalam usaha penangkapan ikan di laut.

Sedangkan dalam ketentuan Undang-Undang Perikanan, mengatur dan membedakan pengertian nelayan menjadi dua yaitu nelayan dan nelayan kecil.

Pasal 1 angka 10: nelayan adalah orang yang mata pencahariannya melakukan penangkapan ikan, sedangkan pada pasal 1 angka 11: nelayan kecil adalah orang yang mata pencahariannya melakukan penangkapan ikan untuk memenuhi kebutuhan hidup sehari-hari yang menggunakan kapal perikanan berukuran paling besar 5 (lima) Gross Ton (GT).

Penjelasan pasal 18 ayat (6) Undang-Undang Republik Indonesia Nomer 32 tahun 2004 tentang Pemerintahan Daerah, yang dimaksud dengan "nelayan kecil" adalah nelayan masyarakat tradisional Indonesia yang menggunakan bahan dan alat penangkapan ikan secara tradisional.

Pembahasan tentang nelayan dalam tataran realitas berdasarkan hasil pengamatan penulis, nelayan dibedakan menjadi: nelayan pemilik (juragan), nelayan penggarap (buruh/pekerja) dan nelayan kecil, nelayan tradisional, nelayan gendong (nelayan angkut), dan perusahaan/industri penangkapan ikan. 
Nelayan pemilik (juragan) adalah orang atau perseorangan yang melakukan usaha penangkapan ikan, dengan hak atau berkuasa atas kapal/perahu dan/atau alat tangkap ikan yang dipergunakan untuk menangkap ikan. Nelayan penggarap (buruh atau pekerja) adalah seseorang yang menyediakan tenaganya atau bekerja untuk melakukan penangkapan ikan yang pada umumnya merupakan/membentuk satu kesatuan dengan yang lainnya dengan mendapatkan upah berdasarkan bagi hasil penjualan ikan hasil tangkapan.

Nelayan tradisional adalah orang perorangan yang pekerjaannya melakukan penangkapan ikan dengan menggunakan perahu dan alat tangkap yang sederhana (tradisional). Dengan keterbatasan perahu maupun alat tangkapnya, maka jangkauan wilayah penangkapannya pun menjadi terbatas biasanya hanya berjarak 6 mil laut dari garis pantai. Nelayan tradisonal ini biasanya adalah nelayan yang turun-temurun yang melakukan penangkapan ikan untuk mencukupi kebutuhan hidupnya.

Nelayan kecil pada dasarnya berasal dari nelayan tradisional hanya saja dengan adanya program modernisasi/motorisasi perahu dan alat tangkap maka mereka tidak lagi semata-mata mengandalkan perahu tradisional maupun alat tangkap yang konvensional saja melainkan juga menggunakan diesel atau motor, sehingga jangkauan wilayah penangkapan agak meluas atau jauh.

Nelayan gendong (nelayan angkut) adalah nelayan yang dalam keadaan senyatanya dia tidak melakukan penangkapan ikan karena kapal tidak dilengkapi dengan alat tangkap melainkan berangkat dengan membawa modal uang (modal dari juragan) yang akan digunakan untuk melakukan transaksi (membeli) ikan di tengah laut yang kemudian akan dijual kembali.

Dalam ketentuan Undang-Undang Perikanan kapal yang tidak digunakan melakukan penangkapan ikan melainkan hanya untuk mengangkut ikan dari lautan menuju pelabuhan atau daratan ini masuk atau dikategorikan sebagai Kapal Pengangkut Ikan/ Kapal Angkut. Kapal pengangkut ikan ini biasanya selain kapal yang hanya membeli ikan dari laut juga merupakan bagian dari Perusahaan Penangkapan ikan yang bertugas mengangkut hasil tangkapan untuk dibawa ke pelabuhan atau daratan.

Perusahaan penangkapan ikan atau industri pena ngkapan ikan adalah perusahaan yang berbadan hukum atau tidak berbadan hukum yang melakukan usaha penangkapan ikan dengan tujuan untuk perdagangan (eksport) atau berorientasi komersiil.
Perusahaan yang bergerak di bidang penangkapan ini memperkerjakan pekerja-pekerja yaitu nahkoda dan pembantu-pembantunya/Anak Buah Kapal (ABK) dan lain-lain dengan sistem upah/gaji.

Pengertian nelayan baik dari sisi yuridis maupun dari sisi relalitas dari uraian di atas menunjukkan adanya ketidakkonsistenan. Antara Penjelasan Undang-Undang Pemerintahan Daerah dengan Undang-Undang Perikanan tidak adanya kesamaan dalam memberikan pengertian nelayan kecil dan nelayan tradisional.

Dalam Undang-Undang Perikanan tidak memberikan rumusan atau pengertian tentang nelayan tradisional, yang dirumuskan dalam pasal 1 angka 11 adalah tentang nelayan kecil, yang menurut penulis pengertian tersebut perlu dikoreksi kembali agar tidak menimbulkan kesalahan dalam interpretasi khususnya pada kriteria ukuran kapal paling besar 5 (lima) Gross Tonage (GT), apabila dikaitkan dengan pengertian nelayan tradisional. Disamping itu juga terdapat perbedaan rumusan nelayan kecil antara yang dirumuskan dalam Undang-Undang Perikanan Pasal 1 angka 11 tersebut dengan penjelasan Pasal 18 ayat (6) Undang-Undang Republik Indonesia No. 32 tahun 2004 tentang Pemerintahan Daerah. Diperlukan perumusan kembali tentang nelayan kecil, dan nelayan tradisional, agar tidak menimbulkan salah persepsi/interpretasi yang berdampak merugikan nelayan Indonesia.

Adanya peristiwa penangkapan nelayan Indonesia oleh Australia, salah satu sebabnya adalah karena adanya perbedaan dalam mengartikan nelayan tradisional khususnya dalam kaitannya dengan kesepakatan kebebasan nelayan tradisional melakukan penangkapan ikan di beberapa wilayah Australia.

Dalam pandangan Australia, bahwa yang dimaksud nelayan tradisional adalah nelayan turun temurun, yang melakukan penangkapan ikan dengan penggunaan kapal atau perahu tradisional (perahu dayung ataupun kapal layar yang tidak dilengkapi dengan motor). Berdasarkan MOU Box 1974, MOU tanggal 7 Nopember 1974 tentang "Memorandum of Understanding between the Gouvernment of Australia and the Gouvernment of the Republic of Indonesia Regarding the Operations of Indonesian Traditional Fishermen in Area's of the Australia Exclusive Fishing Zone and Continental Shelf"'. Dengan demikian MOU tersebut merupakan dasar hukum bagi nelayan tradisional Indonesia untuk melakukan penangkapan ikan di beberapa zona eksklusif Australia dan landas continentalnya yang meliputi: Ashmore Reef, Cartier Islet, Scott Reef, Seringapatam Reef dan Browse 
Islet. Di daerah penangkapan ikan ini nelayan tradisional Indonesia diperbolehkan melakukan penangkapan ikan dan tidak dikenakan peraturan terhadap mereka. Sedangkan dalam Undang-undang Perikanan tidak mengatur nelayan tradisional yang ada adalah nelayan kecil (dengan ukuran kapal di bawah 5 GT) dan dalam kenyataannya menggunakan motor tempel dan bahkan dilengkapi peralatan navigasi, oleh karenanya mereka tidak lagi dianggap sebagai nelayan tradisional, apa yang dilakukan oleh nelayan Indonesia akan cenderung menguras sumber daya ikan Australia dan dianggap mereka sebagai pencuri ikan di wilayahnya. Hal inilah yang kemudian Australia beranggapan bahwa Indonesia melanggar kesepakatan.

Bentuk-bentuk pelanggaran yang sering dilakukan oleh nelayan-nelayan tradisional Indonesia di wilayah perairan Australia (Rokhmin Danuri) diantaranya: Pelanggaran terhadap wilayah operasi yang telah ditetapkan dalam MOU BOX 1974 dan Agreed Minutes 1989. Pelanggaran ini merupakan pelanggaran terbanyak yang dilakukan oleh para nelayan tradisional Indonesia. Hal ini dikarenakan, sebagai akibat dari berubahnya peta wilayah kegiatan para nelayan tradisional Indonesia yang semula tunduk pada MOU BOX 1974 (Ashmore Reef, Cartier Islet, Scott Reef, Seringapatam Reef dan Browse Islet) berubah sesuai dengan Agreed Minutes 1989 (Scott Reef, Seringapatam Reef dan Browse Islet). Dengan kata lain, Ashmore Reef dan Cartier Islet dilarang untuk kegiatan pemanfaatan sumber daya alam hayati. Pelanggaran terhadap ketentuan yang berhubungan dengan pemanfaatan sumber daya alam hayati sesuai dengan kesepakatan, baik sesuai MOU BOX 1974 maupun Agreed Minutes 1989. Salah satu jenis pelanggaran yang sering dilakukan oleh para nelayan tradisional Indonesia adalah pengambilan jenis-jenis biota laut tertentu sebagai bagian dari sumber daya alam hayati yang dilarang seperti pengambilan penyu dan burung beserta telurnya. Pelanggaran terhadap penggunaan fasilitas yang digunakan dalam kegiatan penangkapan ikan, dimana fasilitas tersebut tidak sesuai dengan apa yang telah ditetapkan melalui MOU BOX 1974 dan Agreed Minutes 1989.

Dalam kenyataan, pelanggaran seperti ini terlihat dalam bentuk melakukan kegiatan penangkapan dengan menggunakan perahu yang digerakkan oleh mesin (motor), menggunakan alat-alat penangkapan yang tergolong modern, bahkan menangkap ikan hiu dengan menggunakan gilnet. Pelanggaran yang dilakukan berhubungan dengan masalah lingkungan hidup. Hal ini dapat terlihat antara lain dari tindakan para nelayan yang dapat menimbul- kan kebakaran karena lalai memadamkan api setelah memasak atau membuang puntung rokok tanpa dimatikan terlebih dahulu apinya, ataupun kegiatan lain yang menyebabkan terkontaminasinya sumbersumber air minum pada tempat-tempat dimana para nelayan diperbolehkan untuk mengambil air minum. Pelanggaran lain yang juga sering dilakukan adalah pemanfaatan kegiatan penangkapan ikan ini sebagai sarana untuk mengantar dan memasukkan imigran gelap ke Australia.

Faktor-faktor terjadinya pelanggaran yang dilakukan nelayan-nelayan tradisional Indonesia (Songa Wilhemus Wetan, 2000), yaitu: pengertian nelayan terhadap MOU BOX 1974 maupun Agreed Minutes 1989 masih kurang. Hal ini disebabkan karena tingkat pendidikan mereka yang masih relatif rendah, sehingga sangat besar kemungkinan mereka tidak dapat membaca peta dan karenanya tidak dapat mengenali dengan tepat wilayah operasinya, nama pulau dan daerah yang disebut dalam MOU BOX 1974 maupun Agreed Minutes 1989, mungkin saja berbeda dengan nama yang dikenal sehari-hari oleh tradisional Indonesia. Seperti pulau Pasir yang dinamakan Australia sebagai Ashmore Reef, pulau Baru dinamakan Cartier Islet dan pulau Datu dinamakan Seringapatam Reef, para nelayan tradisional Indonesia kurang mengetahui batas wilayah yang disebut dalam MOU BOX 1974 maupun Agreed Minutes 1989 secara pasti. Hal ini terjadi karena, selain para nelayan tradisional tidak dapat mengerti atau membaca peta, tetapi juga karena tidak terdapat tandatanda yang jelas yang menunjukkan batas-batas sebagaimana yang dimaksudkan oleh MOU BOX 1974 maupun Agreed Minutes 1989.

Para nelayan tradisional pada umumnya tidak dilengkapi dengan peralatan navigasi yang memadai, hasil yang diperoleh dari usaha penangkapan cukup banyak atau memuaskan sehingga para nelayan tidak ingin melakukan kegiatan di bidang usaha lain, dan juga pengaruh faktor sosial dan budaya, dimana keluarga-keluarga tertentu dari masyarakat nelayan tradisional Indonesia asal Papela Rote, setiap tahunnya mengadakan kunjungan ke makam leluhurnya yang meninggal dan dikuburkan di Pulau Pasir (Ashmore Reef). Saat mengunjungi makam ini biasanya dilakukan bersama-sama dengan mencari hasil-hasil laut sebagaimana dilakukan oleh nenek moyangnya sejak beratus-ratus tahun yang lalu. Konsekuensinya dari kegiatan ini adalah bahwa mereka (para nelayan tradisional Indonesia) pasti memasuki wilayah konservasi alam Ashmore Reef, yang seyogyanya dilarang. (Akhmad Solihin, 2010:39-40) 
Keberadaan nelayan secara sosial dan ekonomi, dalam arti jumlah nelayan di Indonesia rata-rata didominasi oleh nelayan penggarap dan nelayan kecil atau nelayan tradisional. Hasil penelitian di Pangkalan Pendaratan Ikan (PPI) Lekok kabupaten Pasuruan jumlah nelayan sebanyak 6.797 orang, yang merupakan nelayan penggarap, nelayan kecil dan nelayan tradisional (BPPI Lekok, 2000). Di Pelabuhan Perikanan Pantai (PPP) Puger Kabupaten Jember jumlah nelayan sampai dengan tahun 2009 tercatat 14.974 orang dengan jumlah armada 2.857 armada, yang ratarata didominasi oleh kapal 5-10 GT (nelayan kecil) (PPP Puger Jember, 2009). Di Pelabuhan Perikanan Pantai (PPP) Mayangan Kota Probolinggo, jumlah nelayan dalam kategori nelayan tetap 2.844 orang, sambilan 412 orang, andon (nelayan yang selalu berpindah) 277, dengan jumlah armada 460 armada (PPP Mayangan Probolinggo, 2009). Di Pelabuhan Perikanan Nusantara (PPN) Brondong Lamongan Jumlah nelayan sampai dengan tahun 2009 tercatat 13.997 orang dengan jumlah alat tangkap 1466 kapal yang terdiri dari kapal perikanan ukuran 11-20 GT dengan alat tangkap yang dominan yaitu dogol atau cantrang (PPN Brondong, 2008). Jumlah nelayan di PPN Pengambengan Jembrana Bali sampai dengan tahun 2009 tercatat 3.050 orang, yang merupakan nelayan penggarap (ABK) dan jumlah armada 185, paling banyak di bawah 10 GT (PPN Pengambengan, 2009). Nelayannelayan tersebut mayoritas adalah anota masyarakat atau penduduk daerah setempat.

Menurut data Dirjen Perikanan Tangkap Departemen Kelautan dan Perikanan jumlah nelayan di Indonesia sampai tahun 2009 tercatat ada 2.752 .490 orang dengan total armada 596.230 unit. Dari keseluruhan jumlah tersebut $90 \%$ nya adalah nelayan kecil dengan bobot mati kapal di bawah 30 GT, dan dalam kenyataannya mayoritas nelayan (nelayan tradisional), nelayan kecil maupun nelayan penggarap, yang melakukan penangkapan ikan untuk memenuhi kebutuhan hidup sehari-hari (subsisten), kecuali perusahaan perikanan yang mana penangkapan ikan memang dilakukan untuk tujuan bisnis atau komersiil dengan menggunakan kapal yang berukuran di atas $30 \mathrm{GT}$.

Banyaknya jumlah nelayan kecil maupun nelayan tradisional yang melebihi kapasitas wilayah tangkapan ikan dapat memicu potensi tangkap lebih (over fishing), hal ini dikarenakan jangkauan wilayah penangkapan nelayan kecil atau tradisional yang terbatas yang tidak sebanding dengan wilayah penangkapan. Kondisi yang demikian juga dapat memicu timbulnya konflik antar nelayan karena perebutan wilayah pe- nangkapan, sebagaimana telah terjadi di wilayah penangkapan ikan selat Madura, di wilayah penangkapan ikan Puger. Sehingga diperlukan solusi untuk pemecahan masalah yang demikian. Salah satu solusi yang telah dilakukan oleh Pemerintah salah satunya adalah memberikan bantuan kapal penangkapan ikan yang berukuran di atas $10 \mathrm{GT}$ agar mereka dapat melakukan penangkapan ikan dengan jangkauan lebih jauh dari sebelumnya.

Pembahasan tentang nelayan khususnya nelayan kecil atau tradisional sangat terkait pula dengan sistem kerja mereka. Pada umumnya jam kerja mereka relatif singkat biasanya cukup satu hari saja (one day fishing). Kondisi atau kebiasaan semacam ini berdampak pada hasil tangkapan yang tidak optimal sehingga mengakibatkan tingkat produksi rendah dan pendapatan mereka juga tidak optimal akibatnya tingkat kesejahteraan nelayan pun rendah. Sistem kerja one day fishing antara lain juga disebabkan kapal dan alat tangkap ikan yang mereka gunakan, selain itu budaya kerja yang hanya satu hari rupanya sudah menjadi kebiasaan. Sehingga program pemerintah dengan peningkatan ukuran kapal dan perubahan pola penangkapan dari satu hari menjadi lebih nampaknya susah untuk dilaksanakan. Kondisi seperti ini menjadi kendala pula dalam kaitannya dengan pendataan maupun pembinaan yang dilakukan Pemerintah atau Pemerintah Daerah.

Pada sisi lain jika kita melihat potensi sumber daya ikan di wilayah laut Indonesia yang begitu besar, namun kemampuan dan budaya nelayan kita masih sangat terbatas. Sektor perikanan tangkap sesungguhnya merupakan sumber kekuatan sosial ekonomi nelayan dan umumnya merupakan salah satu penyangga sektor ekonomi nasional. Jika sektor ini dimanfaatkan secara maksimal serta digarap secara optimal oleh nelayan Indonesia, maka dapat menjadi sumber ekonomi yang sangat besar.

Selain dari sisi jam kerja yang relatif singkat, perlu diketahui, di Indonesia untuk menjadi atau berprofesi sebagai nelayan sangatlah mudah karena tidak diperlukan persyaratan yang khusus baik yang menyangkut keahlian secara khusus maupun ijazah atau formal, sehingga siapa pun dapat menjadi nelayan dan kapan pun mereka mau, tidak dibatasi oleh waktu. Karena itu di negara kita Indonesia masih banyak dijumpai nelayan musiman, yakni nelayan yang melaut hanya pada saat tertentu saja, dan biasanya selain melakukan pekerjaan sebagai nelayan pada kondisi tertentu (musim paceklik) mereka melakukan pekerjaan lain, serta tingkat ketrampilannya mereka pun terbatas sehingga berdampak pada tingkat perolehan mereka. 
Profesi nelayan di Indonesia nampaknya bukan merupakan profesi yang menjanjikan, yang dapat memberikan masa depan baik atau kesejahteraan hidup. Hal ini sangat berbeda dengan kondisi di negara-negara lain, seperti Jepang atau Malaysia, untuk menjadi nelayan di negara-negara tersebut dibutuhkan keahlian dan konsistenitas profesi. Sehingga tingkat kehidupan nelayan di negara-negara tersebut mapan.

Mencermati keadaan sektor perikanan tangkap khususnya tentang jumlah nelayan, dapat dijadikan satu penilaian atau indikator bahwa ternyata sektor perikanan tangkap di Indonesia masih didominasi oleh nelayan tradisional dengan skala penangkapan yang kecil pula. Untuk itu diperlukan langkah-langkah yang dapat merubah keadaan, budaya kerja, serta peningkatan ketrampilan mereka sehingga jumlah tangkapan pun dapat meningkat.

Sistem Bagi Hasil dalam penangkapan ikan sangat berperan pula dalam menentukan tingkat pendapatan nelayan. Dalam sistem pembagian hasil penangkapan ikan pada umumnya diterapkan dengan sistem bagi hasil ini, nelayan pemilik (juragan) mendapatkan bagian hasil lebih banyak dari nelayan penggarap. Sebagai contoh di PPN Brondong Lamongan, sistem bagi hasil disini (Brondong Lamongan) disebut dengan umanan (prosentase). Dalam setiap kapal yang melakukan penangkapan ikan terdapat satu pemilik (juragan/daoke) kapal yang ikut dalam penangkapan ikan. Sedang yang lainnya adalah nelayan penggarap atau Anak Buah Kapal (ABK) yang disebut dengan belah. Dalam setiap kapal penangkapan ikan biasanya terdapat $25 \mathrm{ABK}$ atau tergantung jenis kapal dan alat tangkap yang digunakan (untuk payang biasanya 10-15 ABK dan cantrang antara 10 ABK). Dalam sistem bagi hasil (umanan) penghasilan dibagi $40 \mathrm{~s} / \mathrm{d} 50$ uman (prosen) untuk juragan dan sisanya dibagi untuk ABK. Jika ABK merangkap atau menduduki posisi atau jabatan tertentu, misalnya sebagai nahkoda atau juru pandu, maka dia mendapatkan tambahan umanan lagi, contoh: ABK yang merangkap sebagai juru pandu maka dia mendapatkan 1 uman untuk ABK dan 1 uman untuk posisi sebagai juru pandu. Pada prinsipnya setiap jabatan atau posisi ada bagian masing-masing sehingga kalau ABK merangkap jabatan, maka bagiannya akan bertambah pula. Uman dibagi dalam bentuk uang setelah dipotong pinjaman, selain pembagian dalam bentuk uman ABK mendapat bagian atau jatah 'iwak-iwakan'. Iwak-iwak-an ialah pembagian ikan dalam jumlah yang selayaknya untuk dibawa pulang sebagai lauk pauk. Namun dalam prakteknya iwak-iwak-an ini oleh nelayan lebih banyak dijual daripada dibawa pulang untuk menutupi kebutuhan hidup sehari-hari.

Sistem bagi hasil di PPI Lekok kabupaten Pasuruan pada prinsipnya tidak jauh berbeda dengan di PPN Lamongan. Pendapatan hasil penangkapan setelah dikurangi biaya operasional (solar, alat tangkap, bahan makan, dan uang saku) sisanya dibagi dua yaitu $50 \%$ untuk pemilik perahu (juragan) dan 50\% untuk Anak Buah Kapal (ABK, nelayan penggarap atau pekerja) dengan pembagian untuk alat tangkap Alet Juru Mudi 1,5 bagian, ABK yang tidak merangkap jabatan masing-masing satu bagian, jumlah ABK untuk setiap perahu tidak sama tergantung jenis perahu dan alat tangkapnya. Pembagian untuk alat tangkap Jurung, Juru Mudi mendapat 2 bagian, Juru Rawat 2 bagian, Tukang Panggil 11/4 bagian, dan Tukang Mesin 1 1/4 bagian. Untuk alat tangkap Alet biasanya terdiri 6 ABK, untuk alat tangkap Tak-Tak terdiri 3 ABK dan alat tangkap Jurung 6 ABK. Pendapatan mereka rata-rata per hari antara Rp.15.000-Rp.40.000 bahkan sering kali impas atau tidak mendapatkan hasil. Di Lekok tidak mengenal adanya pembagian "iwak-iwakan" layaknya di Lamongan. Sistem bagi hasil seperti ini (dengan atau tanpa iwak-iwakan) juga terjadi di daerah-daerah nelayan lainnya.

Ketimpangan dalam sistem bagi hasil seperti ini nampaknya sudah menjadi tradisi atau budaya dan nampaknya kondisi seperti ini cenderung dilestarikan, nelayan pemilik modal atau pemilik (juragan) mendominasi para nelayan. Sementara nelayan (penggarap) tidak mempunyai pilihan. Dalam arti karena keterbatasan modal dan skill yang dimiliki oleh nelayan. Disamping itu juga karena budaya atau sikap entrepeneur yang tidak dimiliki oleh nelayan sehingga mereka lebih suka menyediakan tenaga dan resiko nyawanya daripada kehilangan modal. Sedang bagi pemilik (juragan) karena mereka sebagai pemilik modal dengan resiko kehilangan modal maka untuk menghindari atau meminimalkan resiko ini mereka menerapkan sistem bagi hasil sebagaimana dijelaskan di atas, yang kecenderungan dengan segala upaya atau bentuk sistem bagi hasil untuk meminimalisir resiko kerugian yang akan diderita kadang dirasa kurang adil bagi nelayan.

Sistem perdagangan ikan di Tempat Pelelangan Ikan (TPI) yang tidak transparan, yang lebih banyak dikuasai oleh para tengkulak. Sehingga Nelayan tidak ada pilihan. Kondisi ini juga merupakan penyebab bertambahnya derita nelayan.

Dominasi pemilik modal tidak hanya terhadap nelayan bahkan juga terhadap pengelola atau otoritas. Pemerintah (Pusat maupun Daerah) masih sangat 
lemah dalam menegakkan peraturan perdagangan atau lelang ikan. Program-program yang dilakukan oleh Pemerintah maupun Pemerintahan Daerah tidak tepat sasaran, karena sistem yang belum tertata, kebanyakan program dilaksanakan secara parsial. Hal inilah yang menjadi salah satu penyebab rendahnya pendapatan sehingga menimbulkan kemiskinan yang dialami nelayan.

Kemiskinan adalah keadaan dimana terjadi ketidakmampuan untuk dapat memenuhi kebutuhan dasar seperti makanan, pakaian, tempat berlindung, pendidikan, dan kesehatan. Kemiskinan dapat disebabkan oleh adanya kelangkaan alat pemenuh kebutuhan dasar, atau pun sulitnya akses terhadap pendidikan dan pekerjaan. Kemiskinan merupakan masalah global. Sebagian orang memahami istilah ini secara subyektif dan komparatif, sementara yang lainnya melihatnya dari segi moral dan evaluatif, dan yang lainnya lagi memahaminya dari sudut ilmiah yang telah mapan.

Kemiskinan dipahami dalam berbagai cara. Pemahaman utamanya mencakup: a. Gambaran kekurangan materi, yang biasanya mencakup kebutuhan pangan sehari-hari, sandang, perumahan, dan pelayanan kesehatan. Kemiskinan dalam arti ini dipahami sebagai situasi kelangkaan barang-barang dan pelayanan dasar; b. Gambaran tentang kebutuhan sosial, termasuk keterkucilan sosial, ketergantungan, dan ketidakmampuan untuk berpartisipasi dalam masyarakat. Hal ini termasuk pendidikan dan informasi. Keterkucilan sosial biasanya dibedakan dari kemiskinan, karena hal ini mencakup masalah-masalah politik dan moral, dan tidak dibatasi pada bidang ekonomi; c. Gambaran tentang kurangnya penghasilan dan kekayaan yang memadai. Makna "memadai" disini sangat berbedabeda, melintasi bagian politik dan ekonomi di seluruh dunia. Deklarasi Copenhagen menjelaskan kemiskinan absolut sebagai "sebuah kondisi yang dicirikan dengan kekurangan parah kebutuhan dasar manusia, termasuk makanan, air minum yang aman, fasilitas sanitasi, kesehatan, rumah, pendidikan, dan informasi." (http://id.wikipedia.org/wiki/Kemiskinan)

Ukuran Kemiskinan, Bank Dunia menggambarkan "sangat miskin" sebagai orang yang hidup dengan pendapatan kurang dari US\$1 per hari, dan “miskin" dengan pendapatan kurang dari US\$2 per hari. Berdasarkan standar tersebut, 21\% dari penduduk dunia berada dalam keadaan "sangat miskin", dan lebih dari setengah penduduk dunia masih disebut "miskin". (http://id.wikipedia.org/wiki/bankdunia/ Kemiskinan.)

Penyebab kemiskinan banyak dihubungkan dengan berbagai penyebab: a. penyebab individual (patologis), yang melihat kemiskinan sebagai akibat dari perilaku, pilihan, atau kemampuan dari si miskin; b. penyebab keluarga, yang menghubungkan kemiskinan dengan pendidikan keluarga; c. penyebab subbudaya (subcultural), yang menghubungkan kemiskinan dengan kehidupan sehari-hari, dipelajari atau dijalankan dalam lingkungan sekitar; d. penyebab agensi, yang melihat kemiskinan sebagai akibat dari aksi orang lain, termasuk perang, pemerintah, dan ekonomi; e. penyebab struktural, yang memberikan alasan bahwa kemiskinan merupakan hasil dari struktur sosial. (http: //id.wikipedia.org/wiki/Kemiskinan)

Penyebab kemiskinan nelayan di Indonesia sangatlah komplek, penyebab individual, keluarga, subbudaya, agensi maupun struktural saling berkaitan. Menurut Kusnadi, sebab-sebab pokok yang menimbulkan kemiskinan pada nelayan adalah:

a. belum adanya kebijakan, strategi dan implementasi program pembangunan kawasan pesisir dan masyarakat nelayan yang terpadu di antara para pemangku kepentingan pembangunan.

b. adanya inkonsistensi kuantitas produksi (hasil tangkapan), sehingga keberlanjutan aktivitas sosial ekonomi perikanan di desa-desa nelayan terganggu. Hal ini disebabkan oleh kondisi sumber daya perikanan telah mencapai kondisi "over fishing", musim paceklik yang berkepanjangan, dan kenaikan harga bahan bakar minyak (BBM).

c. masalah isolasi geografis desa nelayan, sehingga menyulitkan keluar-masuk arus barang, jasa, kapital, dan manusia, yang mengganggu mobilitas sosial ekonomi.

d. adanya keterbatasan modal usaha atau modal investasi, sehingga menyulitkan nelayan meningkatkan kegiatan ekonomi perikanannya.

e. adanya relasi sosial ekonomi yang "eksploitatif" dengan pemilik perahu, pedagang perantara (tengkulak), atau pengusaha perikanan dalam kehidupan masyarakat nelayan.

f. adalah rendahnya tingkat pendapatan rumah tangga nelayan, sehingga berdampak negatif terhadap upaya peningkatan skala usaha dan perbaikan kualitas mereka. (Direktorat Pemberdayaan Masyarakat Pesisir, 2006:1-2)

Apa yang telah diungkapkan oleh Kusnadi di atas memang demikianlah adanya, bahwa kemiskinan yang dialami oleh nelayan diantaranya disebabkan karena minimnya modal yang dimiliki dan pendidikan nelayan yang rata-rata masih rendah (SD) dan bahkan ada yang tidak menamatkan SD, sehingga kemampuan atau skillnya pun terbatas, kehidupan nelayan yang penuh dengan tekanan dari pemilik modal 
(pemilik kapal/perahu dan tengkulak), adanya ketergantungan antara pemodal dengan nelayan yang terus dilanggengkan (Patron Klien), kebijakan dan program yang kurang tepat sasaran dan sektoral, serta juga diakibatkan oleh budaya atau kebiasaan hidup nelayan yang suka boros, ketika masa panen ikan dimana pendapatan mereka banyak maka biasanya langsung dihabiskan, kurang kesadaran untuk menabung atau berhemat.

Karena mereka (nelayan) miskin maka dalam kehidupan sosial politik pun mereka lemah. Hak politik Nelayan yang meliputi hak pilih dan dipilih tidak semuanya dapat dilaksanakan sesuai dengan cita-cita negara Demokrasi. Kemiskinan yang dialami oleh nelayan rentan untuk menjadi sasaran atau objek eksploitasi pada saat-saat Pemilihan Umum (Pemilu); Presiden, Kepala Daerah atau Wakil Rakyat. Meskipun secara hukum bahwa setiap orang mempunyai hak memilih maupun dipilih, namun karena secara ekonomi mereka (nelayan) miskin dan pendidikan formal yang minim, maka seolah tidak ada peluang baginya untuk dapat menggunakan hak dipilihnya. Mereka hanya menjadi objek eksploitasi oleh pihak-pihak tertentu yang ingin berhasil atau mendapatkan suara terbanyak pada saat pemilihan, setelah berhasil lupa dan tidak ada upaya untuk memperhatikan kehidupan nelayan.

Kemiskinan yang dialami nelayan juga membuat mereka rentan konflik baik internal maupun eksternal. Pelanggaran yang dilakukan nelayan berkaitan dengan pola penangkapan ikan merupakan jalan pintas untuk dapat memperoleh hasil tangkapan yang memadai.

Bahwasanya dari uraian di atas, maka pengertian dan pembedaan nelayan dan nelayan kecil berdasarkan Undang-Undang Perikanan menurut penulis perlu dievaluasi kembali, sebagaimana telah dijelaskan di atas dalam realitas terdapat: a. nelayan pemilik, b. nelayan penggarap, c. nelayan kecil, dan d. nelayan tradisional. Hasil tangkapan nelayan penggarap, nelayan kecil dan nelayan kecil kebanyakan dijual untuk memenuhi kebutuhan hidup sehari-hari.

Disamping itu dari uraian di atas dapat dikatakan pula bahwa ciri khas usaha perikanan di Indonesia yaitu: dominasi perikanan rakyat, artisanal, sub-sistem, skala kecil, modal dan alat tangkap sederhana atau tradisional serta jam kerja yang relatif singkat yaitu satu hari (one day fishing). Kondisi inilah yang menjadi salah faktor mengapa pendapatan mereka rendah yang berdampak pada kemiskinan. Hal ini sekaligus memberikan gambaran bahwa inilah nelayan dan bagaimana kondisi nelayan di Indone- sia. Sehingga diperlukan upaya atau langkah-langkah untuk meningkatkan pendapatan mereka, yang salah satu upaya yang dapat memberi kontribusi yang sangat besar adalah dengan adanya Pelabuhan Perikanan. Kebijakan pemerintah mengenai penanggulangan kemiskinan di dalam masyarakat nelayan nampaknya masih bersifat terpusat, sehingga program-program yang dijalankan tidak sesuai dengan kebutuhan masyarakat atau daerah tertentu. Sehingga banyak program penanggulangan kemiskinan yang menempatkan masyarakat sebagai objek, akibatnya masyarakat kurang berpartisipasi secara aktif dalam menggali potensi dirinya dan lingkungannya untuk keluar dari kemiskinan. Selain itu program-program yang dilaksanakan cenderung bersifat sektoral yang seringkali mengakibatan adanya semangat egosektoral dan saling tumpang tindih. Keadaan ini lebih dipersulit karena umumnya tiap departemen atau instansi mempunyai definisi dan kriteria sendiri tentang kemiskinan. Akibatnya kemiskinan cenderung dipahami secara parsial, dan penanggulangannya cenderung bersifat sektoral.

Hal inilah yang menyebabkan sulitnya menjaga kontinuitas program dan cenderung membuat program baru, dimana program baru tersebut bukan merupakan kelanjutan program lama. Berangkat dari kegagalan dari program penanggulangan kemiskinan sebelumnya, maka diperlukan strategi atau model program penanggulangan yang kemiskinan yang pada prinsipnya menjadikan masyarakat miskin sebagai subjek. Tidak terkecuali apa yang dialami oleh nelayan Indonesia.

\section{PENUTUP \\ Kesimpulan}

Terdapat perbedaan pengertian tentang Nelayan Kecil dan Nelayan Tradisional antara UndangUndang Perikanan, dengan penjelasan pasal 1 ayat (6) Undang-Undang Pemerintahan Daerah dan dalam tataran realita. Kondisi yang demikian berakibat merugikan nelayan.

Dari sisi ekonomi pendapatan nelayan masih sangat rendah, sehingga mereka miskin, hal ini dikarenakan: keterbatasan modal, skill, adanya tekanan dari pemilik modal (sistem bagi hasil perikanan yang tidak adil), sistem perdagangan atau pelelangan ikan yang tidak transparan (tidak ada regulasi yang tepat dan lemahnya otoritas atau pemerintah), budaya kerja yang masih tradisional atau konvensional.

Kemiskinan yang dialami nelayan Indonesia menjadikan mereka lemah baik di sektor sosial, maupun politik. Hukum yang seharusnya memberikan payung 
perlindungan kepada nelayan ternyata belum mampu sepenuhnya melindungi. Begitu juga dalam UndangUndang Perikanan hanya terdapat satu pasal, yaitu Pasal 1 angka 10 dan 11, itupun tentang pengertian nelayan.

\section{Rekomendasi}

Perlu sinkronisasi dan kepastian hukum tentang pengertian atau konsep nelayan kecil atau nelayan tradisional supaya tidak terjadi perbedaan penerapan atau interpretasi. Jaminan perlindungan hukum dan pemberdayaan nelayan sangat diperlukan dan harus senantiasa ditingkatkan sebagai upaya penguatan nelayan sebagai salah satu sumber daya manusia Indonesia, serta meningkatkan kesejahteraan nelayan.

\section{DAFTAR PUSTAKA}

\section{Buku:}

Charles, T. Anthony, 2001, Suistainable Fishery System, Fish and Aquatic Resources Series. Oxford: Blackwell Science.

Nurjaya, I Nyoman, 2009, Menuju Pengelolaan Sumber Daya Alam yang Adil, Demokratis dan Berkelanjutan: Perspektif Hukum dan Kebijakan, dalam Pengelolaan Sumber Daya Alam dalam Perspektif Antropologi Hukum, Jakarta: Prestasi Pustaka Publishier.

Solihin, Akhmad, 2010, Politik Hukum Kelautan dan Perikanan, Isu, Permasalahan dan Telaah Kebijakan, Bandung: Nuansa Aulia.

Songa, Wilhemus Wetan, 2000, Pelaksanaan Perjanjian antara Indonesia dan Australia tentang Hak Perikanan Tradisional dikaitkan dengan Nelayan asal Nusa Tenggara Timur, Tesis, Bandung, Program Studi Ilmu Hukum Program Pascasarjana, Universitas Pajajaran.

W.J.S. Poerwadarminto, 1993, Kamus Umum Bahasa Indonesia, Cetakan XIII, Jakarta: Balai Pustaka.

\section{Peraturan Perundang-undangan:}

Konvensi Hukum Laut 1982.

Undang-Undang Republik Indonesia No. 6 tahun 1964 tentang Bagi Hasil Perikanan.

Undang-Undang Republik Indonesia No. 6 Tahun 1996 tentang Perairan Indonesia.
Undang Undang Republik Indonesia No. 31 tahun 2004 tentang Perikanan.

Undang-Undang Republik Indonesia No. 32 tahun 2004 tentang Pemerintahan Daerah.

Undang-Undang Republik Indonesia No. 43 tahun 2008 tentang Wilayah Negara.

Undang-Undang Republik Indonesia No. 45 Tahun 2009 tentang Perubahan atas Undang-Undang No. 31 Tahun 2004 tentang Perikanan.

\section{Jurnal, Laporan dan Internet:}

Badan Pusat Statistik, Sensus Penduduk Indonesia Tahun 2010.

Danuri, Rokhim, Reorientasi Pembangunan Berbasis Kelautan, ch.roin.yusak-yayat/majalah Tokoh Indonesia No. 7

Data Statistik Perikanan PPP Mayangan Kota Probolinggo Tahun 2009.

Danuri, Rokhim, Reorientasi Pembangunan Berbasis Kelautan, ch.roin.yusak-yayat/majalah Tokoh Indonesia No. 7.

Direktorat Pemberdayaan Masyarakat Pesisir, 2006, 6 Tahun Program PEMP Sebuah Refleksi, Jakarta.

Departemen Kelautan dan Perikanan, Direktorat Jenderal Perikanan Tangkap, 2008, Petunjuk Pelaksanaan Pengelolaan Pelabuhan Perikanan, Jakarta.

Hasil survey dan wawancara dengan Bpk. Sukardono dan Bpk. Suryono Pengawas Perikanan PPN Brondong Kab. Lamongan.

http://id.wikipedia.org/wiki/bankdunia/Kemiskinan http://id.wikipedia.org/wiki/Kemiskinan http://id.wikipedia.org/wiki/Kemiskinan

Informasi Data Statistik Perikanan PPP Puger Kabupaten Jember Tahun 2009.

Kementerian Kelautan dan Perikanan, Pusat Data, Statistik dan Informasi, 2009, Kelautan dan Perikanan dalam Angka 2009.

Laporan Monitoring BPPPI Lekok Tahun 2009.

Laporan Tahunan PPN Pengambengan 2009.

Rohmin Danuri, http://www.mail.archieve.com/ pelaut@yahoo.group.com/ms90.1166.

Statistik Perikanan Pelabuhan Perikanan Nusantara Brondong tahun 2008.

Wikipedia Indonesia, 2004, http://id.wikipedia.org/ wiki. Ensiklopedia berbahasa Indonesia. 